\title{
Lichen Sebagai Bioindikator Pencemaran Udara Di Gerbang Kota (Gateway) Kota Jambi
}

\author{
Febri Juita Anggraini ${ }^{*}$, Ria Resti Oktapiani' ${ }^{2}$ Freddy Ilfan $^{3}$, dan Zuli Rodhiyah ${ }^{4}$ \\ 1,2,3,4 Program Studi Teknik Lingkungan Universitas Jambi \\ *e-mail: febri_juita@unja.ac.id
}

\begin{abstract}
The gateway of city is the point of entry and exit for traffic activities, the high traffic activity that occurs causes air pollution, thereby reducing air quality. The use of lichen as a bioindicator is considered more efficient than using other indicator tools or machines. Purpose of this study was to determine the level of air pollution at the gateway of Jambi city using lichen as a bioindicator and to determine the concentration of Pb metal content in lichen. The research method used is exploration with roaming methods. The location of the research was carried out at the West Gate of Simpang Rimbo, the South Gate of Paal 10, and the East Gate of Aurduri 2. The Pb metal test in lichen was carried out using Inductively Coupled Plasma Mass Spectroscopy analysis method (ICP-MS). Based on the measurement results, the Aurduri 2 location is included in the location of low traffic density with an average number of 18,509 vehicles/ day. The location with moderate traffic density is Paal 10 with an average number of 31,941 vehicles/ day. The vehicle traffic density with the highest number was the Simpang Rimbo location with an average number of 45,041 vehicles/ day. The highest concentration of Pb in lichen was at the Aurduri 2 sampling location with a Pb metal value of $3.01 \mathrm{ppm}$ and the lowest at the Simpang Rimbo location of $2.31 \mathrm{ppm}$.
\end{abstract}

Keywords: Air Pollution; Lichen; Gateway; Pb Concentration

\section{Pendahuluan}

Gerbang kota (gateway) merupakan pintu keluar masuknya aktivitas lalu lintas kendaraaan dari dan menuju suatu Kota. Kota Jambi sebagai ibukota dari provinsi Jambi dan merupakan penghubung antar tiga provinsi yaitu Sumatera Barat, Riau, dan Sumatera Selatan, juga berfungsi sebagai simpul jasa dan arus perkembangan teknologi bagi daerah sekitarnya. Hal tersebut menyebabkan padatnya aktivitas kendaraan dan masyarakat pada gerbang kota Jambi, menurut Handika dkk (2019) total rata-rata kendaraan yang masuk melalui gerbang jalan ke arah Kota Jambi sebanyak 435.684/hari dengan komposisi jenis kendaraan beragam mulai dari sepeda motor, mobil roda empat hingga truk barang yang menempuh perjalanan jarak jauh atau antar daerah. Aktivitas lalu lintas kendaraan pada gerbang kota tersebut diperkirakan dapat menimbulkan pencemaran dan penurunan kualitas udara. Maka dari itu perlu dilakukannya pemantauan kualitas udara di gerbang kota Jambi untuk mencegah terjadinya pencemaran udara yang lebih jauh.

Ada beberapa metode yang bisa digunakan untuk pemantauan pencemaran udara. Salah satunya menggunakan parameter biologis dengan bioindikator. Bioindikator adalah organisme yang bisa digunakan untuk identifikasi dan penentuan kualitatif faktor lingkungan yang dihasilkan manusia (Conti dan Cecchetti, 2000). Bioindikator pencemaran udara yang banyak digunakan adalah lumut kerak (lichen) yang sering kali ditemukan di batang pohon pada sepanjang jalan raya.

Lumut kerak atau lichen adalah salah satu organisme yang digunakan sebagai bioindikator pencemaran udara. Penggunaan lichen sebagai bioindikator dinilai lebih efisien dibandingkan menggunakan alat atau mesin indikator ambien yang dalam pengoperasiannya memerlukan biaya yang besar dan penanganan khusus (Loopi et.al,2002). Lichen memberikan respon secara ekofisiologis yang berbeda terhadap perubahan lingkungan tersebut. Respon lichen terhadap kandungan logam dapat dijadikan sebagai alat untuk memonitor kandungan logam di udara (Jamhari, 2010).
Timbal atau Plumbum $(\mathrm{Pb})$ merupakan logam sebagai bahan pencemar utama di udara (Jamhari,2010). Menurut Koinstein (2002) $\mathrm{Pb}$ merupakan salah satu polutan yang bersumber dari sektor transportasi dan industri. Partikel timbal yang terlepas ke udara dalam asap kendaraan bermotor berukuran 0,02-1,00 $\mu \mathrm{m}$, dengan masa tinggal di udara mencapai 4-40 hari (Naria, 2005). Hal tersebut bisa meningkatkan potensi terpaparnya manusia oleh partikel $\mathrm{Pb}$ melalui sistem pernafasan. Semakin banyaknya jumlah kendaraan bermotor berpotensi untuk meningkat nilai $\mathrm{Pb}$ dalam atmosfer. Keberadaan $\mathrm{Pb}$ di atmosfer akan memberikan sejumlah dampak pada penerimanya, menurut Manahan (1992) paparan $\mathrm{Pb}$ yang berlangsung lama dapat mengakibatkan gangguan terhadap berbagai sistem organ seperti darah, sistem syaraf, ginjal, sistem reproduksi dan saluran cerna. Menurut Palar (1994), konsentrasi Pb yang tinggi di udara dapat mengganggu pembentukan sel darah merah. Gejala keracunan dini mulai ditunjukkan dengan terganggunya fungsi enzim untuk pembentukan sel darah merah, pada akhirnya dapat menyebabkan gangguan kesehatan lainnya seperti anemia, kerusakan ginjal.

\section{Metode Penelitian}

\subsection{Waktu dan Tempat Penelitian}

\section{Waktu Penelitian}

Pengukuran jumlah kendaraan dilakukan selama kurang lebih 14 hari dengan dengan 3 waktu perhitungan yang mewakili jam-jam sibuk pada gerbang kota yaitu pagi hari (06.00-09.00), siang hari (11.00-14.00), dan sore hari (15.0018.00) pada masing masing lokasi penelitian.

\section{Tempat Penelitian}

Penelitian di lakukan di jalan arteri Kota Jambi yang berfungsi sebagai jalan yang menuju gerbang masuk (gateway) Kota Jambi. Berdasarkan Peraturan Daerah Kota Jambi nomor 9 tahun 2013 tentang Rencana Tata Ruang Wilayah (RTRW) Kota Jambi tahun 2013-2033 dimana tiga (3) jalan merupakan jalan-jalan sebagai gerbang (gateway) 
menuju Kota Jambi. Tiga (3) gerbang tersebut diantaranya 1. gerbang Simpang Rimbo, 2. Paal 10 dan 3. Jembatan Aurduri 2. Adapun lokasi penelitian dapat dilihat pada tabel dan gambar 1 berikut.

Tabel 1. Lokasi Gerbang Masuk (Gateway) Kota Jambi Gerbang Lokasi

\begin{tabular}{cl}
\hline Gerbang Barat & Dari arah Jambi Luar Kota, \\
(Simpang Rimbo) & Sumatera Barat dan Riau ke arah \\
lampu merah Simpang Rimbo \\
Gerbang Selatan (Paal & Dari Sumatera Selatan, Mestong \\
10) & ke arah lampu merah paal 10 \\
Derbang Timur & Dari arah Kumpeh, Tanjung \\
(Jembatan Aurduri 2) & Anung Timur, Barat kearah Pasar \\
& Angso Duo. \\
\hline
\end{tabular}

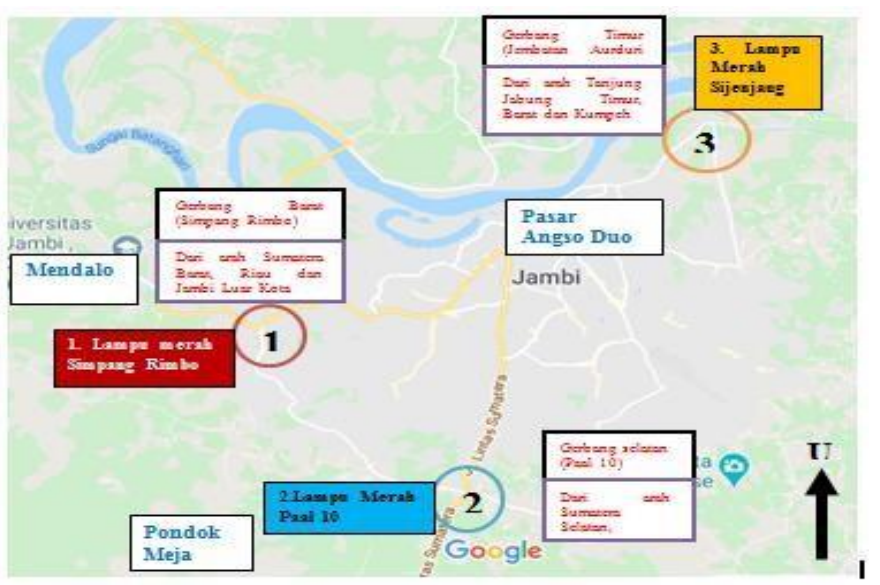

Gambar 1. Peta Lokasi Penelitian

\subsection{Pengambilan Sampel Lichen}

Pengambilan sampel dilakukan secara eksplorasi dengan metode jelajah. Sampel lichen diambil dari batang pohon yang tumbuh disepanjang Jalan kawasan Gerbang Kota (gateway) yang telah ditentukan dengan cara di kerik menggunakan pisau. Pengambilan sampel untuk koloni lichen dilakukan dengan membuat plot berukuran $10 \mathrm{x} 10 \mathrm{~cm}^{2}$. Sampel lichen diambil dari batang pohon berdasarkan ketentuan pembagian zona (Mursisi,et al, 2000) dengan mengambil zona 2 dimana polusi dari kendaraan banyak menempel, selain itu pada zona ini lichen juga banyak dijumpai daripada zona lainnya. Batas ketinggian pengambilan sampel dilakukan $\pm 120 \mathrm{~cm}$ dari permukaan tanah. Jarak pengambilan plot sampel dari titik lokasi yang telah ditentukan yaitu sejauh $\pm 100 \mathrm{~m}$ (Mafaza,2019).

Penelitian ini dilaksanakan di gerbang kota (gateway) menuju Kota Jambi dengan beberapa ruas jalan yang telah ditentukan melalui beberapa tahapan yaitu: Tahap persiapan, tahap pelaksanaan, tahap Uji laboratorium untuk mengetahui konsentrasi logam $\mathrm{Pb}$ pada lichen dan tahap penghitungan data. Pengambilan data berupa sampel dilakukan selama kurang lebih satu minggu pada masing-masing ruas Gerbang Kota (gateway) Kota Jambi yang telah ditentukan.

\subsection{Analisis Data}

\section{Analisis faktor lingkungan}

Adapun faktor lingkungan yang mendukung dalam penelitian ini yaitu terkait dengan pengukuran suhu, kelembaban dan arah angin. Pengukuran suhu, dan kelembaban digunakan alat LCD Digital Hygrometer.

Data arah angin didapat dengan menggunakan alat Mini Anemometer Digital dan untuk mengetahui arah angin dilakukan secara manual menggunakan kompas.

\section{Perhitungan kendaraan}

Perhitungan kendaraan dilakukan pada ruas kiri dan kanan jalan Gerbang Kota Jambi, dengan lamanya perhitungan kurang lebih 14 hari menggunakan alat Digital Hand Tally Counter. Menurut Manual Kapasitas Jalan Indonesia (1997: 1-7) bagian kendaraan yang dihitung dalam survei kendaraan ini sebagai berikut.

a. kendaraan ringan LV (Light Vehicle)

b. kendaran berat HV (Heavy Vehicle)

c. Sepeda Motor

3. Uji laboratorium terhadap kandungan logam $\mathrm{Pb}$ pada lichen

Analisis konsentrasi logam $\mathrm{Pb}$ yang terdapat pada lichen dilakukan dengan metode analisis Inductively Coupled Plasma Mass Spectroscopy (ICP-MS). Teknologi ICP-MS merupakan teknologi yang melakukan pengukuran unsur berdasarkan nomor massa dan yang mempunyai limit deteksi yang rendah. Analisis dengan teknologi ICP-MS dilakukan di laboratorium Universitas Andalas. Hasil dari pada analisis ini nantinya akan dibuat secara deskriptif terkait konsentrasi logam $\mathrm{Pb}$ yang terkandung pada lichen pada tiap tiap lokasi penelitian.

\section{Hasil Dan Pembahasan}

\subsection{Faktor Lingkungan}

Pengukuran faktor lingkungan pada penelitian ini dilakukan untuk melihat pengaruh suhu, kelembaban serta kecepatan angin dalam pertumbuhan dan keberadaan lichen di lokasi penelitian. Pengukuran dilakukan sebanyak 3 kali pengulangan yaitu pada pagi hari (pukul 07.00 wib), pada siang hari (pukul 12.00 wib) dan pada sore hari (pukul 17.00 wib) selama 14 hari sehingga didapatkan pengukuran rata-rata parameter lingkungan di masing-masing lokasi penelitian seperti pada tabel 2 berikut.

Tabel 2. Perhitungan rata-rata faktor lingkungan

\begin{tabular}{llcccc}
\hline \multirow{2}{*}{ No } & \multirow{2}{*}{ Parameter Abiotik } & \multicolumn{3}{c}{ Hasil pengukuran } & \multirow{2}{*}{$\sum$ rata-rata seluruh lokasi } \\
\cline { 2 - 5 } & & $\sum$ Simpang Rimbo & $\sum$ Paal10 & $\sum$ Aurduri 2 & 31,5 \\
2 & Suhu udara ( C) & 31,4 & 31,2 & 31,8 & 59,3 \\
3 & Kelembaban Udara (\%) & 61 & 60 & 57 & 1,8 \\
\hline
\end{tabular}

Keberadaan lichen dipengaruhi oleh faktor abiotik dan faktor biotik. Faktor abiotik meliputi seperti suhu, kelembaban, serta kecepatan angin, sedangkan faktor biotik meliputi substrat lichen (Marianingsih, 2017). Faktor fisik yang diamati pada penelitian ini adalah suhu, kelembaban dan kecepatan angin. 
Menurut Murningsih (2016), mengatakan bahwa untuk suhu optimal pertumbuhan lichen yaitu dibawah $40^{\circ} \mathrm{C}$ dan untuk kelembaban udara menurut Furi et al, (2016) lichen banyak menyukai tempat kering dengan kelembaban yang berkisar antara 40\%-69\%. Untuk perhitungan parameter lingkungan di gerbang Kota Jambi menunjukkan hasil bahwa gerbang kota memiliki suhu rata-rata $31,5^{\circ} \mathrm{C}$ dan kelembaban udara rata-rata di lokasi sampling adalah sebesar 59,3\%, berdasarkan hasil penelitian tersebut suasana lingkungan abiotik gerbang Kota Jambi memiliki nilai yang baik untuk pertumbuhan lichen.

Kecepatan angin rata-rata pada tiap lokasi penelitian sebesar $1,8 \mathrm{~m} / \mathrm{s}$, kecepatan angin juga berpengaruh terhadap pertumbuhan lichen, sejalan dengan penelitian yang dilakukan oleh Sancho dan Keppen (1989), menyatakan kecepatan angin yang lebih tinggi dapat meningkatkan penyerapan polutan secara difusi oleh thallus lichen.

\subsection{Pengukuran Kepadatan Lalu Lintas}

Pertumbuhan dan perkembangan ekonomi Kota Jambi secara langsung mengakibatkan meningkatnya pergerakan arus barang dan manusia yang keluar masuk kota Jambi. Pencemaran yang disebabkan dari sumber bergerak seperti kendaraan bermotor, maupun mobil hingga truk trailer mempunyai kontribusi terbesar terhadap penurunan kualitas udara ataupun pencemaran udara (Ismiyati, dkk, 2014). Lokasi penelitian terletak pada gerbang kota, gerbang kota merupakan jalur lalu lintas perbatasan antar kota dan termasuk kedalam kelompok Jalan Arteri. Jalan Arteri merupakan jalan yang melayani angkutan utama dengan ciri-ciri perjalanan jarak jauh, kecepatan rata-rata tinggi dan jumlah jalan masuk dibatasi secara efisien yang diatur dalam Undang-Undang RI No. 13 Tahun 1980. Gerbang kota menjadi salah satu fokus penting dalam daerah pemantauan pencemaran udara, karena letaknya yang menghubungkan daerah satu dengan yang lainnya, terdapat aktivitas berupa transportasi dan kegiatan masyarakat sekitar. Gerbang kota Jambi merupakan salah satu jalur yang menghubungkan Kabupaten Muaro Jambi dan Kota Jambi, yang terdiri atas gerbang Barat (Simpang Rimbo), gerbang Selatan (Paal 10), dan gerbang Timur (Auduri 2).

Pengukuran kepadatan lalu lintas dihitung selama 14 hari di masing-masing lokasi penelitian. Berdasarkan hasil pengamatan, lokasi Aurduri 2 termasuk ke dalam lokasi dengan kepadatan lalu lintas rendah dengan jumlah rata-rata
18.509 kendaraan/hari. Lokasi dengan kepadatan lalu lintas sedang yaitu Paal 10 dengan jumlah rata- rata 31.941 kendaraan/hari. Kepadatan lalu lintas kendaraan dengan jumlah tertinggi adalah lokasi Simpang Rimbo dengan jumlah rata-rata 45.041 kendaraan/hari. Data kendaraan perhari pada masing-masing lokasi penelitian dapat dilihat pada tabel 3 berikut.

Tabel 3. Perhitungan Rata-rata kendaraan Tiap Lokasi Penelitian

\begin{tabular}{|c|c|c|}
\hline No & Lokasi Penelitian & $\begin{array}{c}\sum \text { perhitungan kendaraan } \\
\text { rata-rata perhari }\end{array}$ \\
\hline 1 & Simpang Rimbo & 45.041 \\
\hline 2 & Paal 10 & 31.941 \\
\hline 3 & Aurduri 2 & 18.509 \\
\hline
\end{tabular}

Lokasi penelitian gerbang Simpang Rimbo, terletak pada bagian barat Kota Jambi. Gerbang Simpang Rimbo merupakan gerbang menuju Kota Jambi yang paling ramai dilalalui aktivitas lalu lintas. Hal ini dikarenakan lokasi ini berbatasan sekaligus menjadi gerbang menuju pusat kampus dan pusat kabupaten sehingga ramai aktivitas lalulintas maupun masyarakat yang melewati lokasi ini. Penelitian yang dilakukan pada lokasi ini terletak pada jalur lampu merah yang menghubungkan aktivitas lalulintas menuju pusat kota.

Lokasi penelitian Gerbang Paal 10, terletak pada bagian selatan Kota Jambi. Gerbang Paal 10 merupakan gerbang menuju Kota Jambi yang cukup ramai dilalui aktivitas lalu lintas. Hal ini dikarenakan lokasi ini berbatasan sekaligus menjadi gerbang menuju pusat pusat kota sehingga ramai aktivitas lalu lintas maupun masyarakat yang melewati lokasi ini.

Lokasi penelitian Gerbang Aurduri 2, terletak pada bagian Timur Kota Jambi. Gerbang Aurduri 2 merupakan jalur penghubung menuju Kota Jambi yang cukup ramai dilalui aktivitas lalu lintas. Hal ini dikarenakan lokasi ini berbatasan sekaligus menjadi gerbang menuju pusat pusat kota, selain itu sekitaran wilayah lokasi ini merupakan pusat industri sehingga ramai aktivitas lalulintas maupun aktivitas masyarakat serta industri pada lokasi ini.

Hasil perhitungan rata-rata kepadatan lalu lintas selama 14 hari berdasarkan jenis kendaraan di lokasi Simpang Rimbo, Pall 10 dan Aurduri 2 tersaji pada tabel 4, 5 dan 6.

Tabel 4. Perhitungan Rata-rata Kepadatan Lalu Lintas Lokasi Simpang Rimbo

\begin{tabular}{|c|c|c|c|c|c|c|}
\hline \multirow{2}{*}{ Hari } & \multicolumn{5}{|c|}{ Jenis kendaraan } & \multirow{2}{*}{$\begin{array}{c}\sum \text { Rata rata } \\
\text { kendaraan/har }\end{array}$} \\
\hline & $\sum$ Sepeda Motor & $\sum$ Mobil & $\sum \mathrm{LDV}$ & $\sum \mathrm{HDV}$ & $\sum \mathrm{Bus}$ & \\
\hline Senin & 10501 & 5887 & 764 & 3182 & 38 & 6791 \\
\hline Selasa & 10381 & 5158 & 905 & 3530 & 33 & 6669 \\
\hline Rabu & 12118 & 4923 & 689 & 3753 & 31 & 7171 \\
\hline Kamis & 10090 & 4569 & 765 & 3069 & 30 & 6367 \\
\hline Jumat & 9094 & 3626 & 878 & 2637 & 40 & 5425 \\
\hline Sabtu & 11632 & 4358 & 1189 & 2552 & 37 & 6589 \\
\hline Minggu & 10535 & 3788 & 790 & 2928 & 46 & 6029 \\
\hline Total & 74351 & 32309 & 5980 & 21651 & 255 & 45041 \\
\hline
\end{tabular}

Keterangan: - LDV ( Light Duty Vehicles ) = Pick Up, Angkot - HDV ( Hight Duty Vehicles ) = Truck,Puso 
Febri Juita Anggraini, Ria Resti Oktapiani, Freddy Ilfan dan Zuli Rodhiyah, Lichen Sebagai Bioindikator Pencemaran Udara Di Gerbang Kota (Gateway) Kota Jambi

Tabel 5. Perhitungan Rata-rata Kepadatan Lalu Lintas Lokasi Pall 10

\begin{tabular}{|c|c|c|c|c|c|c|}
\hline \multirow{2}{*}{ Hari } & \multicolumn{5}{|c|}{ Jenis kendaraan } & \multirow{2}{*}{$\begin{array}{c}\sum \text { Rata-Rata } \\
\text { Kendaraan/hari }\end{array}$} \\
\hline & $\sum$ Sepeda Motor & $\sum$ Mobil & $\sum \mathrm{LDV}$ & $\sum \mathrm{HDV}$ & $\sum$ Bus & \\
\hline Senin & 9016 & 2789 & 595 & 2354 & 15 & 4923 \\
\hline Selasa & 8494 & 2729 & 638 & 2114 & 22 & 4666 \\
\hline Rabu & 7526 & 2746 & 559 & 1900 & 21 & 4251 \\
\hline Kamis & 7880 & 2806 & 654 & 2320 & 30 & 4467 \\
\hline Jumat & 7490 & 2662 & 678 & 2506 & 32 & 4456 \\
\hline Sabtu & 8309 & 2716 & 622 & 2631 & 28 & 4769 \\
\hline Minggu & 7689 & 2837 & 602 & 2076 & 27 & 4410 \\
\hline Total & 56404 & 19285 & 4348 & 15901 & 175 & 31941 \\
\hline
\end{tabular}

Keterangan: - LDV ( Light Duty Vehicles ) = Pick Up, Angkot

- HDV ( Hight Duty Vehicles )= Truck,Puso

Tabel 6. Perhitungan Rata-rata Kepadatan Lalu Lintas Lokasi Aurduri 2

\begin{tabular}{|c|c|c|c|c|c|c|}
\hline \multirow{2}{*}{ Hari } & \multicolumn{5}{|c|}{ Jenis Kendaraan } & \multirow{2}{*}{$\begin{array}{c}\sum \text { Rata-Rata } \\
\text { Kendaraan/hari }\end{array}$} \\
\hline & $\sum$ Sepeda Motor & $\sum$ Mobil & $\sum \mathrm{LDV}$ & $\sum \mathrm{HDV}$ & $\sum$ Bus & \\
\hline Senin & 7036 & 1143 & 407 & 944 & 1 & 3178 \\
\hline Selasa & 6514 & 1090 & 337 & 858 & 1 & 2934 \\
\hline Rabu & 6222 & 1055 & 381 & 916 & 1 & 2859 \\
\hline Kamis & 6369 & 1210 & 437 & 995 & 0 & 2993 \\
\hline Jumat & 4018 & 1059 & 356 & 1003 & 0 & 2146 \\
\hline Sabtu & 4250 & 820 & 288 & 983 & 1 & 2115 \\
\hline Minggu & 4141 & 1140 & 460 & 1111 & 0 & 2285 \\
\hline Total & 38554 & 7520 & 2669 & 6813 & 4 & 18509 \\
\hline
\end{tabular}

Keterangan: - LDV ( Light Duty Vehicles ) = Pick Up, Angkot

- HDV ( Hight Duty Vehicles $)=$ Truck,Puso

Perhitungan volume lalu lintas dilaksanakan selama 14 hari serta dihitung selama 9 jam yang mewakili jam sibuk pada pagi, siang dan sore hari. Sistem dengan perhitungan kendaraan ini sebelumnya pernah dilakukan oleh Indratmo, (2006) yang menghitung kendaraan setiap 3 jam sekali yang mewakili jam sibuk pada lokasi tertentu. Perhitungan kendaraan dilakukan menggunakan digital hand tally counter. Jenis kendaraan yang dihitung berpedoman pada Manual Kapasitas Jalan Indonesia (1997:1-7), terdapat beberapa jenis kendaraan diantaranya sepeda motor, mobil, LDV ( Light Duty Vehicles ) Pick Up, Angkot, HDV ( Hight Duty Vehicles ) Truck, Puso dan Bus.

Dari pengukuran kendaraan didapatkan bahwa jenis kendaraan sepeda motor mendominasi dan paling banyak ditemui pada ketiga lokasi penelitian. Selanjutnya jenis kendaraan mobil, truck dan sejenisnya, pickup dan sejenisnya, serta yang paling sedikit adalah jenis kendaraan bus. Beragamnya jenis kendaraan yang terdapat pada saat pengukuran disebabkan karakteristik lokasi penelitian yang merupakan gerbang kota,dan jalur lalu lintas keluar dan masuknya kota, dan bahkan jalur keluar masuknya kendaraan antar provinsi. Sehingga beragamnya jenis kendaraan ini, secara tidak langsung mempengaruhi polusi yang ditimbulkan.

\subsection{Uji Logam Pb (Timbal) pada Lichen}

Spesies lichen yang diujikan untuk mengetahui unsur logam $\mathrm{Pb}$ adalah spesies lichen Dirinaria sp. Lichen dengan jenis spesies ini paling banyak ditemukan dan tersebar di seluruh lokasi penelitian. Pada lokasi sampling Simpang Rimbo, Paal 10 dan Aurduri 2 ditemukan koloni lichen Dirinaria sp sebanyak 383, 193 dan 322 koloni.

Sampel Dirinaria sp. diambil sebanyak 2 kali pegulangan untuk diujikan ke laboratorium. Hasil karakterisasi logam yang dilakukan di Laboratorium Teknik Lingkungan Universitas Andalas dengan menggunakan metode ICP-MS (Inductively Coupled Plasma Mass Spectroscopy) terdapat unsur logam $\mathrm{Pb}$ tertinggi sebesar 3,01 ppm di lokasi Aurduri 2 dan kemudian diikuti kandungan logam $\mathrm{Pb}$ terendah di lokasi Simpang Rimbo sebesar 2,31 ppm. Hal ini dapat dilihat pada tabel 7 berikut.

Tabel 7. Hasil Uji Logam Pb pada Lichen

\begin{tabular}{ccccccc}
\hline \multicolumn{3}{c}{ Lokasi Penelitian } \\
\hline \multirow{2}{*}{ Konsentrasi Logam $(\mathrm{ppm})$} & \multicolumn{4}{c}{ Simpang Rimbo } & \multicolumn{3}{c}{ Paal 10 } & \multicolumn{3}{c}{ Aurduri 2 } \\
& $s p 1$ & $s p 2$ & $s p 1$ & $s p 2$ & $s p$ 1 & $s p 2$ \\
\hline $\mathrm{Pb}$ & 2,55 & 2,31 & 2,61 & 2,47 & 3,01 & 2,87 \\
\hline
\end{tabular}

Berdasarkan penelitian Amin (2012), penyerapan logam berat pada beberapa tanaman termasuk lichen pada dasarnya dipengaruhi oleh beberapa hal diantaranya jangka waktu tanaman kontak dengan logam berat, kadar logam, morfologi dan fisiologi tanaman atau lichen, umur tanaman atau lichen serta tutupan tanaman yang berada pada sekitar lokasi penelitian. Pada pengujian logam berat ini sampel lichen yang digunakan adalah spesies Dirinaria sp. Spesies jenis ini merupakan yang paling banyak ditemukan dan tersebar pada seluruh lokasi penelitian. Spesies ini memiliki ciri-ciri berwarna hijau keabuan dengan permukaan tengah lebih gelap dari pada bagian ujungnya, memiliki thallus foliose (berdaun), gambar Dirinaria sp tersaji pada gambar 2. 


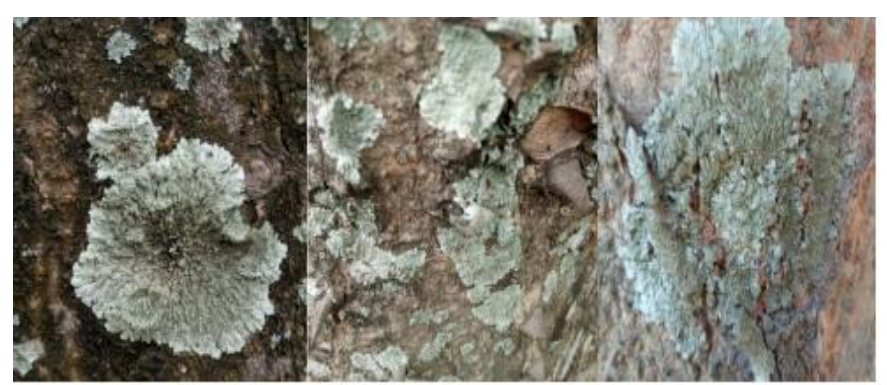

Gambar 2. Dirinaria sp.yang ditemukan pada lokasi penelitian

Berdasarkan penelitian Hasirin, dkk, (2015) lichen dengan tipe thallus foliose merupakan spesies lichen yang dapat mentoleransi pencemaran udara dengan baik. Penyerapan logam berat melalui daun seringkali terjadi karena logam diudara jatuh dan mengendap pada permukaan daun sehingga akan menurunkan proses fotosintesis baik secara langsung maupun tidak langsung (Amin, 2012). Zat pencemar akan mempengaruhi keberadaan lichen serta berpengaruh terhadap pertumbuhannya. Menurut Jamhari (2010) bahwa hasil investigasi dari beberapa kota besar menunjukan bahwa ada korelasi yang signifikan antara konsentrasi logam berat $(\mathrm{Fe}, \mathrm{Mn}, \mathrm{Cu}$ dan $\mathrm{Pb}$ ) di udara dengan yang terdapat pada lichen.

Berdasarkan pengujian laboratorium secara keseluruhan Aurduri 2 memiliki nilai konsentrasi logam yang tinggi dibandingkan lokasi lainnya. Hal ini diduga karena pada sekitar lokasi ini terdapat banyak kawasan industri sehingga berkontribusi pada kadar $\mathrm{Pb}$ di lichen pada dan umur lichen yang terpapar pencemaran sudah dalam periode yang cukup lama dibandingkan lokasi lainnya. Kawasan padat lalu lintas merupakan kawasan dengan kadar pencemar tertinggi, karena jarak pohon relatif dekat dengan jalan raya dan banyaknya kendaraan yang melewati kawasan ini sehingga emisi gas buang kendaraan langsung menempel pada pohon di pinggir jalan. Semakin dekat tanaman dengan sumber emisi maka logam yang terabsorbsi akan semakin banyak (Ihrom dan Sulistyarsi, 2015).

Konsentrasi $\mathrm{Pb}$ pada lichen termasuk ke dalam salah satu konsentrasi logam tinggi yaitu berkisar antara 2,3-3,0 ppm. Menurut ketetapan Kementrian Lingkungan Hidup Nasional nilai $\mathrm{Pb}$ pada penelitian ini sudah melebihi baku mutu, untuk nilai standar $\mathrm{Pb}$ berdasarkan KLH sebesar 2 $\mu \mathrm{g} / \mathrm{Nm} 3$. Penelitian yang sama juga dilakukan oleh Amin (2012), dimana kandungan $\mathrm{Pb}$ pada lichen didapatkan berkisar 2,32 ppm sampai dengan 6,07 ppm yang menandakan nilai tersebut sudah melebihi baku mutu.

\section{Kesimpulan}

1. Berdasarkan hasil pengamatan, Lokasi Aurduri 2 termasuk kedalam lokasi kepadatan lalu lintas rendah dengan jumlah rata-rata 18.509 kendaraan/hari. Lokasi dengan kepadatan lalu lintas sedang yaitu Paal 10 dengan jumlah rata- rata 31.941 kendaraan/hari. Kepadatan lalu lintas kendaraan dengan jumlah tertinggi adalah lokasi Simpang Rimbo dengan jumlah rata-rata 45.041 kendaraan/hari.

2. Konsentrasi logam $\mathrm{Pb}$ pada lichen yang tertinggi terdapat pada lokasi sampling konsentrasi logam yang tertinggi pada lichen berada di Aurduri 2 dengan nilai yaitu logam $\mathrm{Pb}$ sebesar 3,01 ppm dan yang terendah di lokasi Simpang
Rimbo sebesar 2,31 ppm.

\section{Ucapan Terima Kasih}

Penelitian ini didanai oleh dana PNPB Fakultas Sains dan Teknologi Universitas Jambi Tahun 2020

\section{Daftar Pustaka}

Amin.M.Z. 2012. Analisis Kandungan Timbal (Pb) pada Tallus Lichen di Kabupaten Lamongan. Skripsi. Jurusan Biologi Fakultas Sains dan Teknologi Universitas Islam Negeri Maulana Malik Ibrahim Malang.

Conti dan Cecchetti, 2000. Biological Monitorig: Lichens as Bioindicators of Air Pollution Assesment- a Review. Environmental Pollution

Furi et, al. 2016. Eksplorasi lichen di Sepanjang Jalan Raya Solo Tawamangu dan Kawasan Hutan Sekipan Karanganyar Jawa Tengah. Jawa Tengah

Handika, Rizki Andre, dkk. 2019. Analisis Beban Emisi Kendaraan di Gerbang Masuk Jalan-Jalan Arteri ke Kota Jambi

Hasairin, Ashar., dan Siregar, Rosliana. 2018. Analisis Populasi Liken Makro Epifitik sebagai Bioindikator Kualitas Udara di Kawasan Terminal Pinang Baris Kota Medan. Prosiding Seminar Nasional Pendidikan Biologi.

Ihrom, A., dan Sulistyarsi, A. 2015. Biomonitoring Pencemaran Udara Menggunakan Bioindikator Lichenes di Kota Madiun. Florea Volume 2 no. 2

Indratmo, Dunat. 2006. Kajian Kapasitas Jalan dan Derajat Kejenuhan Lalu Lintas di Jalan Ahmad Yani Surabaya. Surabya. Jurnal Aplikasi ISSN. 1907-753X.

Ismiyati, dkk. 2014. Pencemaran Udara Akibat Gas Buang Kendaraan Bermotor. UMJ. Jakarta

Jamhari, Mohammad. 2010. Hubungan Kandungan Timbal $(\mathrm{Pb}) \quad \mathrm{Di}$ Udara Dengan $\mathrm{Pb}$ dalam Talus LichenXanthoparmelia Xanthofarinos. Palu.

Koistien, Kimmo. 2002. Exposure of an Urban Adult Population to PM2,5 Laboratory.

Koistinen, Kimmo. 2002. Exposure of an Urban Adult Population to PM2,5. Laboratory of Air Hygiene, University of Kuopio, Finland. ISSN 0359- 3584.

Loopi et.al 2002. Biodiversity of Ephypitic Lichens and Air Pollution in the Town of Siena (Central Italy, Environmental Pollution).

Mafaza, Husna, dkk. 2019. Keanekaragaman JenisLichen di Kota Semarang. Laboratorium Ekologi dan Biosistematika, Universitas Diponegoro. Semarang.

Manahan S.E.1992. Toxicological chemistry. New York : Lewis Publishers.

Manual Kapasitas Jalan Indonesia. 1987

Marianingsih, Pipit, dkk. 2017. Keanekaragaman Liken Pulau Tunda Banten Sebagai Konten Pembelajaran Keanekaragaman Hayati Berbasis Potensi Lokal. Universitas Sultan Ageng Tirtayasa.

Murningsih, dkk. 2016. Jenis-jenis Lichen di Kampus UNDIP Semarang. Jurnal Bioma Vol. 18, No 1.

Mursisi, et al. 2001. Studi Keanekragaman Anggrek Epifit di Hutan Jabolarangan. Jurnal Biodiversity. 
Febri Juita Anggraini, Ria Resti Oktapiani, Freddy Ilfan dan Zuli Rodhiyah, Lichen Sebagai Bioindikator Pencemaran Udara Di Gerbang Kota (Gateway) Kota Jambi

Naria E. 2005. Mewaspadai Dampak Bahan Pencemar Timbal $(\mathrm{Pb})$ di Lingkungan Terhadap Kesehatan. Jurnal Komunikasi Penelitian volume 17 ( 4).

Peraturan Daerah Kota Jambi nomor 9 tahun 2013 tentang Rencana Tata Ruang Wilayah (RTRW) Kota Jambi tahun 2013-2033

Sancho and Keppen. 1989. Indicators in Environmental protection. Ellis Horwood. New York. 